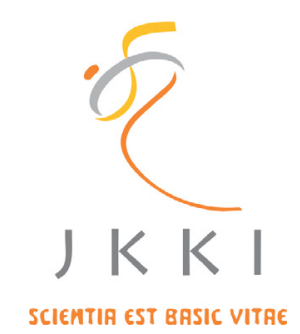

Jurnal Kedokteran dan Kesehatan Indonesia

Indonesian Journal of Medicine and Health

Journal homepage : www.journal.uii.ac.id/index.php/JKKI

\title{
Preliminary study of $\alpha$-mangosteen nanoparticles in the sunscreen cosmeceutical product
}

Hanny Setyowati*1, Wahyuning Setyani²

${ }^{1}$ Department of Research and Development, Borobudur Natural Industry, Semarang, Indonesia

${ }^{2}$ Faculty of Pharmacy, Sanata Dharma University, Yogyakarta, Indonesia

Article Review

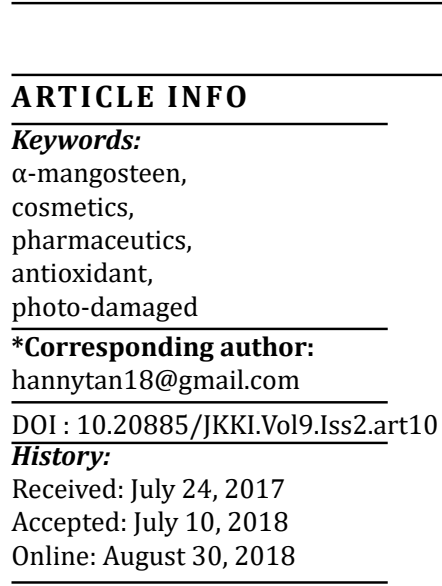

Copyright@2018 Authors. This is an open access article distributed under the terms of the Creative Commons Attribution-NonCommercial $\quad 4.0$ International Licence (http:// creativecommons.org/licences/ by-nc/4.0/).

\section{ABSTRACT}

The growing interest in the cosmeceuticals by natural products has fostered research on the screening of plant-derived raw materials for identifying new antioxidants. Fruit peels as sources of powerful natural antioxidants are often the waste parts of various fruits from daily consumption or food industry. Among the fruit peels, mangosteen peel is an essential source of natural phenolic antioxidants. The $\alpha$-mangosteen, known as the first compound of Garcinia mangostana L, has the most potent antioxidant activity among the other substances. The new application into sunscreen product will be potentially based on their activity to inhibit the photodamaged caused by free radical elements from ultraviolet A and B (UVA and UVB). Thus, this formulation into a nanoparticle product may achieve a better effect and efficacy both as cosmetics and pharmaceutics.

Meningkatnya minat pada sediaan cosmeceutical yang berasal dari bahan alam telah mendorong pencarian bahan aktif tanaman guna mendapatkan senyawa antioksidan baru. Kulit buah sebagai sumber utama antioksidan alami sering ditemukan dari limbah hasil konsumsi sehari-hari atau industri makanan. Beberapa diantaranya yakni, kulit buah manggis yang merupakan sumber utama antioksidan fenolik alami. Senyawa $\alpha$-mangostin, yang dikenal sebagai senyawa utama pada kulit buah manggis, memiliki aktivitas antioksidan yang lebih tinggi dibandingkan senyawa lain. Aplikasi terbaru ke dalam produk tabir surya sangat potensial diterapkan berdasarkan aktivitasnya menghambat kerusakan kulit akibat radikal bebas yang berasal dari sinar UVA dan UVB. Oleh karena itu, formulasi nanopartikel diharapkan dapat mencapai efek dan efikasi kerja yang lebih baik, dari segi kosmetik maupun pengobatan.

\section{INTRODUCTION}

Garcinia mangostana L. (Clusiaceae), commonly known as mangosteen or the queen of fruits, is a slow-growing tropical evergreen tree with leathery, glabrous leaves. The principal secondary metabolites of mangosteen are $\alpha$-mangosteen which has substantial activities, like antifungal, antimicrobial, antioxidant, and cytotoxic activities. ${ }^{1}$

The benefit of $\alpha$-mangosteen has been reported, primarily for antioxidant properties based on in-vitro and in-vivo evaluation test. The antioxidant analysis of hydrogen peroxide inhibition, free radical reduction, UV-A and UV-B prevention has been done and proved results succesfully. At the lower concentration, $\alpha$-mangosteen showed the satisfying effects, so this compound was a potent active compound. ${ }^{2}$

Sunscreens which can belong to cosmeceutical product are widely used to protect the skin 
from harmful effects of sun rays on exposure. The word "cosmeceutical" is used to define a product that suitable position between a drug and cosmetics. This terminology used in the professional skin care area to represent a product that has determinable biological action in the skin, like a drug. The cosmeceutical has been regulated as a cosmetic since it claims to modify appearance. The overview of cosmeceutical is not only for skincare but also for prevention and treatment, like sunscreen reflecting UVA and UVB rays from permeating into the deeper layers of skin, and is less irritating. ${ }^{3}$

Nanotechnology becomes a particular place to develop the active cosmeceuticals. Incorporation of nanotechnology in cosmeceuticals has some benefits, such as increasing the solubility, improve absorption into the skin, and repair damaged skin, smoothly and more efficiently. Several substances such as vitamins, unsaturated fatty acids, and antioxidants can ameliorate the stability of cosmetic ingredients by encapsulating it within the nanoparticles. Delivering active ingredients into the deeper layers of skin is the advantages of using cosmeceuticals products. Using smaller particles of active mineral (e.g., in mineral sunscreens) admits them to be administered without leaving a remarkable white cast). ${ }^{3}$ Therefore, the $\alpha$-mangosteen nanoparticles have a potential activity to be developed for cosmeceutical products.

\section{Mangosteen (Garcinia mangostana)}

Mangosteen (Garcinia mangostana Linn) is a fruit that grows in the Asian region such as Malaysia, Myanmar, Thailand, Philippines, Sri Lanka and India. It is also known as the "queen of fruits" because of its unique and delectable tropical taste. The fruit is dark purple or reddish and contains soft and juicy edible white pulps inside. The flavour is slightly acidic, sweet, and it has a pleasant smell. ${ }^{4}$

Mangosteens are small (about 4 to $8 \mathrm{~cm}$ in diameter) round fruits with a thick, brittle, deep purple spherical outer shell or pericarp. The eatable snow white endocarp of the mangosteen is arranged in a circle of wedge-shaped, 4- to 8-segmented arils. The fruit has a long history of medicinal use in both Chinese and Ayurvedic medicine. For centuries, people in Southeast Asia have used dried mangosteen pericarp for therapeutic aims such as an antiseptic, an antiinflammatory, an antiparasitic, an antipyretic, an analgesic, and as a treatment for skin rashes. ${ }^{5}$

Purified mangosteen elements have demonstrated a variety of biological activities, such as xanthones, flavonoids, and tannin. The effects of purified mangosteen xanthones as antioxidants, and on targets related primarily to infectious diseases, cancer, inflammation, on the modulation of specific receptor-binding sites, and also inhibition the growth of Mycobacterium tuberculosis. ${ }^{6,7}$

\section{Xanthon}

Xanthones are a class of polyphenolic compounds with a skeleton of a xanthene-9-one, (Figure 1) and they have a distinctive chemical structural component that is represented as the tricyclic aromatic ring system. The structure of the xanthene-9-one is symmetrical, and carbons are counted based on a biosynthetic convention. Natural xanthones can be subdivided, based on the nature of substituents, into simple

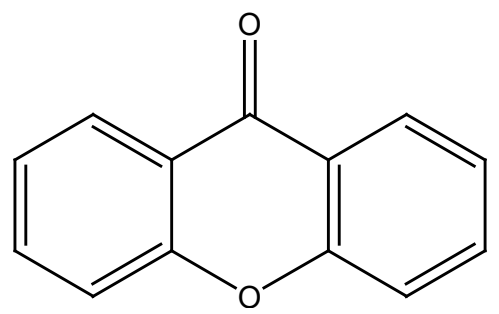

Figure 2. Xanthone. 
oxygenated xanthones, glycosylated xanthones, prenylated xanthones and their derivatives, xanthone dimers, and xanthonolignoids.8 Like flavonoids, xanthones may be distributed in glycoside form, linked with glucose. Otherwise, xanthones have polarity profiles. ${ }^{9,10}$

Xanthones have a unique chemical structure composed of a tricyclic aromatic system (C6C3-C6). Isoprene, methoxyl and hydroxyl groups located at various locations on the $\mathrm{A}$ and $\mathrm{B}$ rings, resulting in a diverse array of xanthone compounds. The purified methods, for example, Thin Layer Chromatography (TLC), High-Performance Liquid Chromatography (HPLC), UV-Vis Spectrophotometry, Infrared Spectrophotometry, Mass Spectrophotometry, and nuclear magnetic resonance Spectrophotometry (NMR Spectrophotometry) can result in several isolates from xanthones. ${ }^{11}$ Alpha -mangosteen was found as dominant in the pericarp extract (Figure 2). The other new xanthones, such as $\beta$-mangosteen garcinone, mangostenone $A$, mangostenone $B$, several known xanthones, trapezifolixanthone has been isolated from this plant. ${ }^{12,13}$ Another report by Mohamed et al. (2014) the isolation and structural elucidation of two new xanthones: mangostanaxanthones I and II have antioxidant activities with the half maximal inhibitory concentration (IC50) 12.07 and $14.12 \mu \mathrm{M}$ by $\alpha$, $\alpha$-diphenyl- $\beta$-picrylhydrazyl (DPPH) free radical scavenging methods respectively. ${ }^{14}$

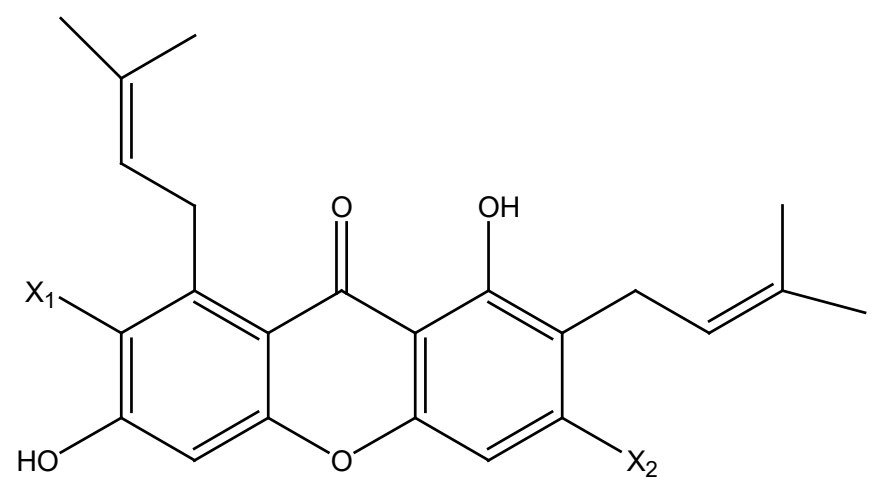

Figure 2. Mangosteen structure as main compound in the Garcinia mangostana pericarpium extract, alpha- mangosteen $\left(\mathrm{X} 1=-\mathrm{OCH}_{3}, \mathrm{X} 2=-\mathrm{OH}\right)$, beta mangosteen $\left(\mathrm{X} 1=\mathrm{X} 2=-\mathrm{OCH}_{3}\right)$ and gamma mangosteen $(\mathrm{X} 1=\mathrm{X} 2=\mathrm{OH})$

\section{Nanotechnology}

Nanoparticles (NP) are a type of colloidal drug delivery system composing particles with a size range from 10 to $1000 \mathrm{~nm}$ in diameter and are used to deliver the drugs or biomolecules. The word 'nano' is derived from the Latin word, which means dwarf. Nano size refers to one thousand million of a particular unit thus nanometer is one thousand millionth of a meter (i.e., $1 \mathrm{~nm}=10^{-9} \mathrm{~m}$ ). ${ }^{15}$ They are drug carriers of natural, semisynthetic, and synthetic polymeric nature in the nanometer size range. ${ }^{16}$ Several nanotechnology innovations are nanoemulsion, nano pigment, liposomes, noisomes, solid lipid nanoparticles, dendrimers and particulate systems like nanotubes, nanocrystal, fullerenes, nanotopes, dan nanospheres. ${ }^{17-19}$

The preparation of $\alpha$-mangosteen has been done by Ahmad et al. (2012) using Poly- $N$ isopropylacrylamide(PNIPAM) as a matrix. ${ }^{20}$ Another method was conducted by Aisha et al. (2012) applying solvent evaporation method with Polyvinylpyrrolidone K 30 (PVP K-30). ${ }^{21}$ These results are a solid form of nanomicelles with the size of 99-127 nm. The combination between eudragithigh water permeability (RL100) and eudragitlow water permeability (RS100) was sufficient to produce nanoparticle at drug loading and entrapment efficiency of $20 \%$ and $>95 \%$, respectively. 22 The in-vitro studies by Rismana et al. (2014) showed that biopolymer of chitosan (as a drug carrier) were 
effective against Propionibacterium acnes with the lowest concentration of about $0.15 \% .^{23}$ The formulation of $\alpha$-mangosteen-encapsulated ethyl cellulose (GME-EC) and a polymer blend of ethyl cellulose and methyl cellulose (GME-EC/MC) nanoparticles can give the higher cellular uptake and accumulation of GME was higher for GMEencapsulated nanoparticles compared to free GME.

Nanosized ultrafine inorganic sunscreens have the advantage of having both UV-reflecting and UV-absorbing properties. UV attenuation is the sum of scattering and absorption and depends on several factors including a dispersion of the inorganic particles, particle size, and refractive index. With decreasing particle size, UV protection shifts towards protection to shorter UV wavelengths. In other words, smaller particles attenuate shorter wavelengths of UV radiation. By transmission electron microscopy (TEM) studies of UV attenuation and particle size, it is also known that nanoparticles reflect and absorb UV light most efficiently at the aggregate size (Figure 3 ), at the average aggregate size of approximately $100 \mathrm{~nm}$. Therefore, the percutaneous absorption can be achieved and play a role as sunscreen (barrier) protecting from skin damage. ${ }^{24}$

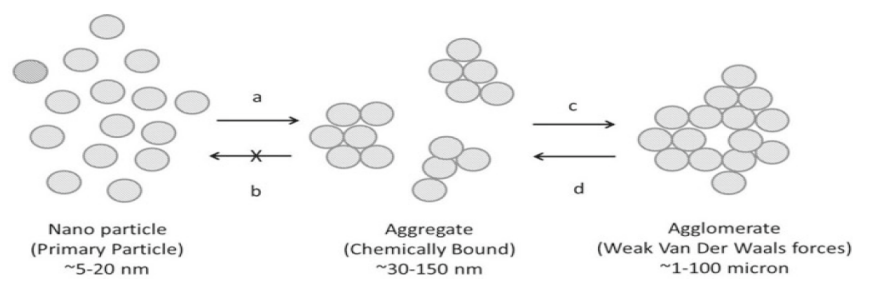

Figure 3. Formation of aggregates and agglomerates from nanoparticle building blocks. ${ }^{24}$

\section{Cosmeceutical}

Cosmeceuticals usually contain active ingredients such as vitamins, phytochemicals, enzymes, antioxidants, and essential oils and can be applied to products such as creams, lotions, and ointments. Therefore, cosmeceuticals have recently attracted increased concern because of their beneficial effects on human health. ${ }^{25}$
Several ingredients that have been used for cosmeceuticals were salicylic acid, glycolic acid (AHA), arbutin, ceramide, ascorbic acid, vitamin $\mathrm{E}$, and active components from plants that have a role for antiinflammation, skin regeneration, moisturizers, sunscreen, and antihiperpigmentation, as seen in Figure $4 .^{26}$

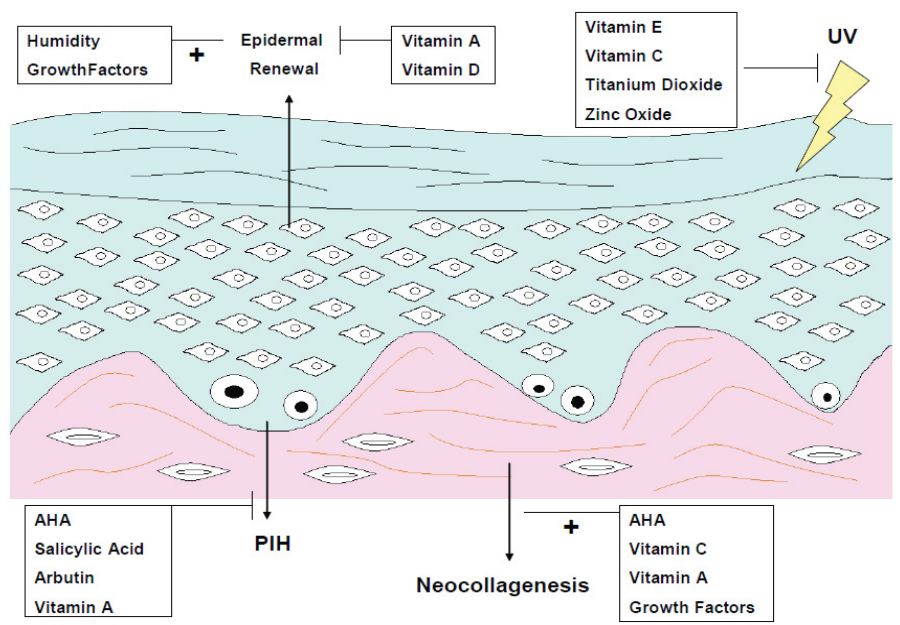

Figure 4. Cosmeceutical agent mechanism ${ }^{26}$, AHA: Alphahydroxyacid, PIH: Post-inflammatory hyperpigmentation, UV: ultraviolet light 


\section{Application of cosmeceutical Antioxidant}

The antioxidant is a substance that can delay or prevent the oxidation process by inhibiting the initiation or propagation of oxidation chain reaction. Antioxidants can protect cells, especially skin cells against damage caused by Reactive Oxygen Species (ROS), such as oxygen singlet, superoxide, peroxide free radical, hydroxyl free radical. ${ }^{27}$ Antioxidant act through several mechanisms: free radical scavenging, chelating of metal ion, reducing activity and quenching of singlet oxygen. Antioxidants have two main types, i.e., primary and secondary antioxidants according to their protective properties at different stages in the oxidation process and various action mechanisms. ${ }^{28}$

Primary antioxidant, also called chainbreaking antioxidants, are compounds capable of neutralising lipid free radical, mainly by stopping their radical state by hydrogen transfer and, periodically by low reactivity compounds. These relatively stable compounds cannot participate in the propagation of the lipid peroxidation, hence the breaking of the chain reaction. Primary antioxidant is active during the induction period. In their presence, oxidation starts later. Primary antioxidant is formed of molecules of phenol, tocopherol, gallic acid and its derivatives, flavonoids, and other compounds. ${ }^{28}$ Secondary (preventive) antioxidant prevent lipid oxidation in a different way, inhibiting the initiation by the fact that they oxidate themselves instead to oxidize lipid molecules, or they turn intermediary or final products generated during the reactions into non-toxic forms. ${ }^{29}$ Zarena et al. (2009)and Tjahjani et al. (2014) evaluated that $\alpha$-mangosteen was contained in the ethyl acetate and acetone fraction, respectively. ${ }^{30,31}$ The inhibition of DPPH, Superoxide Dismutase (SOD), and total antioxidant status (TAS) activity showed the better efficacy, which at the low concentration $125 \mu \mathrm{g} / \mathrm{mL}$ resulted in the high antioxidant activity.

Bioavailability of a xanthone-rich mangosteen liquid in healthy human volunteers after the acute consumption of $59 \mathrm{~mL}$ of the supplement was successfully obtained. The fluid contained mangosteen, aloe vera, green tea, and multivitamins. Results indicated that $\alpha$-mangosteen and vitamins B2 and B5 were bioavailable, with the observed time of maximum observed concentration $\left(\mathrm{T}_{\max }\right)$ of around one hour. The antioxidant capacity measured with the oxygen radical absorbance capacity (ORAC) assay was increased with a maximum effect of $18 \%$ after two hours, and the increased antioxidant level lasted at least four hours. The antioxidant capacity measured with ORAC assay was enhanced with a maximum effect of $18 \%$ after two hours, and the increased antioxidant level lasted at least four hours. ${ }^{32}$

\section{Sunscreens}

Skin aging may occur from a convoluted process which involving either intrinsic or extrinsic factors such as genetic, hormonal, metabolic changes, and particular environmental exposure (UV rays). Further, recovery of skin damage could result from the combat of specific enzymes and biomarkers such as elastase, hyaluronidase, tyrosinase, and matrix metalloproteinases (MMP's). ${ }^{33,34}$

Ultraviolet A and ultraviolet B can induce matrix metalloproteinase. As their name suggests, MMPs degrade dermal matrix proteins, specifically collagens, through enzymatic activity. UV-induced MMP-1 initiates a split of type I and III collagen, continued with degradation by MMP-3 and MMP-9. When the degradation by MMPs is occurring, collagen molecules may keep on cross-linked within the matrix of dermal collagen. Thus, it may harm dermis structural integrity. Since there is a lack of perfect repair mechanisms, MMP-mediated collagen damage can accumulate with UV exposure. This collective damage to the dermal matrix collagen will appear on the clinical manifestation of photodamaged skin. ${ }^{35}$

Donglikar and Deore (2016) possessed that UV rays contact initiates photo-oxidative reactions to activate protein kinase $C$ enzyme and reactive oxygen species which further reacts with protein lipids and DNA to form 
cyclobutane pyridine dimmers. ${ }^{36}$ That action leads to erythema, edema, skin sunburn and cell apoptosis. UV irradiation triggers growth factor cell as well as cytokine receptors on keratinocytes and fibroblasts. This is essential for cell proliferation. UV-driven formation of hydrogen peroxide controls the activity of tyrosine kinase of the epidermal growth factor receptor. Evidence found that the inhibition of protein tyrosine phosphatases is an impact of UV-induced ROS formation. A high level of protection of UVA is strongly suggested, this is due to UVA radiation is linked with aging effects. Therefore, sunscreen is a vital component of anti-aging formulation.

Alpha mangosteen is one of polyphenols compound, which mainly found in the mangosteen peel extract. The compounds are metabolites which work as antioxidant, antiinflammatory and anti-microbial effect. This substance can play a role as sunscreen, prevent the damage of skin caused by UV light and oxidative stress (Table 1 ). ${ }^{37}$

Table 1. In vitro activities of polyphenols ${ }^{37}$

\begin{tabular}{ll}
\hline & Activity \\
\hline Antioxidant activity & Free radical scavenging capacity, measured by the inhibition of \\
stable radicals: & DPPH $(2,2$-diphenyl-1-picrylhydrazyl), ABTS (2,20-azino-bis \\
& $(3-$-ethylbenzothiazoline-6-sulphonic acid) $)$, peroxynitrite \\
& $\left(\mathrm{ONOO}^{-}\right)$, superoxide anion $\left(\mathrm{O}^{-2}\right)$, hydroxyl radicals \\
& Oxygen radical absorbance capacity (ORAC) assay; superoxide \\
& dismutase (SOD) assay; \\
& ferric reducing antioxidant potential (FRAP) assay \\
& Inhibition lipid oxidation (liposomes, thermal acceleration of oils) \\
& Anti-elastase activity \\
& Anti-collagenase activity \\
& Anti-hyaluronidase activity \\
Inhibition of skin's enzymes & UVB-Irradiated human HaCaT keratinocytes, comet assay \\
Prevention of oxidative DNA-damages, & Fibroblasts stressed with $\mathrm{H}_{2} \mathrm{O}_{2}$ \\
increasing cell viability, & UV-irradiated normal human epidermal keratinocytes (NHEK) \\
reduction of intracellular ROS & Inhibitory effects on the release of inflammatory mediators such \\
Anti-inflammatory activity & as IL-6, IL-8, prostaglandin-E2 in HaCaT cells, NHEK, fibroblasts \\
Inhibition of UV or heat-induced & Activity of MMP1, MMP2, MMP3, hyaluronidase gene expression \\
enzyme release & in human dermal fibroblasts. \\
\hline
\end{tabular}

Sun protection activity test has been done by Liandhajani et al. (2013). ${ }^{38}$ The fraction of ethanol extract from mangosteen pericarp that gives the highest sunscreen activity was the $n$-hexane fraction. Another purification of n-hexane fraction using HPLC obtained a yellow crystal, collected from fractions eluted with hexane-EtOAc (9:1 to 8:2). This compound giving sunscreen protection (SPF) valued 21.76 at 50 ppm and 37.8 at $100 \mathrm{ppm}$ and considered as the main contributor for the sunscreen activity of the n-hexane fraction, using $1 \mathrm{H}-\mathrm{NMR}$ and

\section{C-NMR (Figure 5).}

Alpha-mangosteen in the Garcinia mangostana pericarpium extract can increase the collagen biosynthesis, based on Fitri et al. (2016)39. At $50 \%$ concentration, the administration of mangosteen extract into mice exposed to UV $B$ radiation during four weeks can protect the dermis. The collagen thickness and density in the treatment group had no significant results with the normal group. This results indicated that $\alpha$-mangosteen is capable of preventing the skin damage caused by UV radiation. 


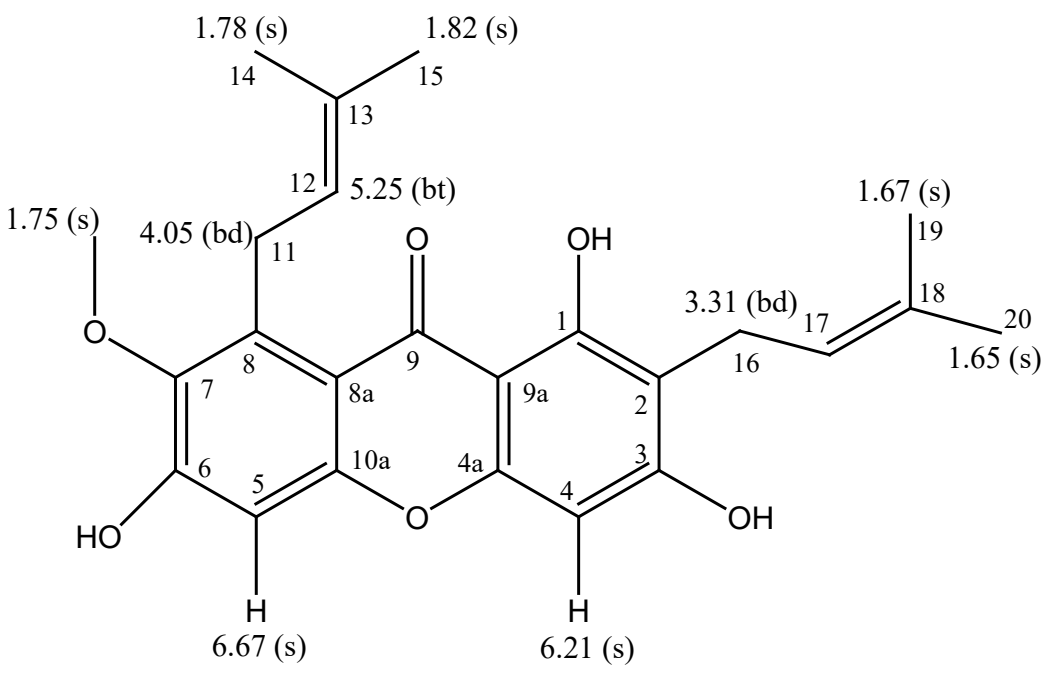

Figure 8. $\alpha$-mangosteen chemical structure

\section{CONCLUSIONS}

The $\alpha$-mangosteen is potential as sunscreen cosmeceutical products, based on their efficacy in-vitro and in-vivo evaluation. Further study of other plants, especially waste material from natural products, can increase the value of products to be developed both for pharmaceutics and cosmetics.

\section{CONFLICT OF INTEREST}

We declare theres no conflict of interest

\section{Acknowledgement}

none declared.

\section{REFERENCES}

1. Jung HA, Su BN, Keller WJ, Mehta RG, Kinghorn AD. Antioxidant xanthones from the pericarp of Garcinia mangostana (Mangosteen). Journal of Agricultural and Food Chemistry. 2006;54(6):2077-82.

2. Susanti M, Dachriyanus, Putra DP, Susanti M. Aktivitas perlindungan sinar UV kulit buah Garcinia mangostana Linn secara in vitro. Pharmacon. 2012; 13 (2): 61-4.

3. Lohani A, Verma A, Yadav N, Karki N. Nanotechnology-based cosmeceuticals. ISRN Dermatology. 2014; 2014:1-14.

4. Ibrahim MY, Hashim NM, Mariod AA, Mohan S, Abdulla MA, Abdelwahab SI, et al. $\alpha$-Mangostin from Garcinia mangostana
Linn: An updated review of its pharmacological properties. Arabian Journal of Chemistry. 2016;9(3):317-29.

5. Shibata M, Iinuma M, Morimoto J, Kurose $\mathrm{H}$, Akamatsu K, Okuno Y, et al. $\alpha$-Mangostin extracted from the pericarp of the mangosteen (Garcinia mangostana Linn) reduces tumor growth and lymph node metastasis in an immunocompetent xenograft model of metastatic mammary cancer carrying a p53 mutation. BioMed Central Medicine. 2011;9:1-18.

6. Chaverri JP, Rodriguez NC, Ibarra MO, Rojas JMP. Medicinal properties of mangosteen (Garcinia mangostana). Food and Chemical Toxicology. 2008;46:3227-39.

7. Chin YW, Kinghorn AD. Structural characterization, biological effects, and synthetic studies on xanthones from mangosteen (Garcinia mangostana): A popular botanical dietary supplement. Mini-Reviews in Organic Chemistry. 2008;5(4):355-64.

8. Obolskiy D, Pischel I, Siriwatanametanon N, Heinrich M. Garcinia mangostana L.: A phytochemical and pharmacological review. Phytotherapy Research. 2009;23:1047-65.

9. Karthiga P, Soranam R, Annadurai G. Karthiga P, Soranam R, Annadurai, G. Alpha-mangostin, the major compound from Garcinia mangostana Linn responsible for synthesis of Ag Nanoparticles: Its characterization and evaluation studies. Research 
Journal of Nanosciences and Nanotechnology. 2012;2(2):46-57.

10. Aishaa AFA, Abu-Salah KM, Ismail Z, Majid AMSA. Determination of total xanthones in Garcinia mangostana fruit rind extracts by ultraviolet (UV) spectrophotometry. Journal of Medicinal Plants Research. 2013;7(1):29-35.

11. Orozco FG, Failla ML. Biological activities and bioavailability of mangosteen xanthones: A critical review of the current evidence. Nutrients. 2013;5:3163-83.

12. Suksamrarn S, Suwannapoch N, Ratananukul P, Aroonlerk N, Suksamrarn A. Xanthones from the green fruit hulls of Garcinia mangostana. American Chemical Society and American Society of Pharmacognosy. 2002; 65(5):761-3.

13. Jindarat S. Xanthones from mangosteen (Garcinia mangostana): Multi-targeting pharmacological properties. Journal of the Medical Association of Thailand. 2014;97(2):197-201.

14. Mohamed GA, Ibrahim SRM, Shaaband MIA, Ross SA. Mangostana xanthones I and II, new xanthones from the pericarp of Garcinia mangostana. Fitoterapia. 2014;98:21521.

15. Malodia K, Singh SK, Mishra DN, Shrivastava B. Nanoparticles: An advance technique for drug delivery. Research Journal of Pharmaceutical, Biological and Chemical Sciences. 2012;3(3):1186-208.

16. Martien R, Adhyatmika, Irianto IDK, Farida V, Sari DP. Perkembangan teknologi nanopartikel sebagai sistem penghantaran obat. Majalah Farmaseutik. 2012;8(1):13344.

17. Kaur IP, Agrawal R. Nanotechnology: A new paradigm in cosmeceuticals. Recent Patents on Drug Delivery and Formulation. 2007;1:171-82.

18. Sharma B, Sharma A. Future prospect of nanotechnology in development of anti-ageing formulations. International Journal of Pharmacy and Pharmaceutical Sciences. 2012;4(3):57-66.

19. Nagavarma BVN, Yadav HKS, Ayaz A, Vasudha LS, Shivakumar HG. Different techniques for preparation of polymeric nanoparticles - A review. Asian Journal of Pharmaceutics and Clinical Research. 2014;5(3):16-23.

20. Ahmad M, Yamin BM, Lazim AM. Preliminary study on dispersion of $\alpha$-mangostin in PNIPAM microgel system. The Malaysian Journal of Analytical Sciences. 2012;16(3):256-61.

21. Aisha AF, Abu-Salah KM, Ismail Z, Majid AM. Solid dispersion of $\alpha$-mangostin improve its aqueous solubility through self-assembly of nanomicelles. Journal of Pharmaceutical Sciences. 2012;101(2):815-25.

22. Aisha AFA, Abu-Salah KM, Ismail Z, Abdulmajid AMS, Alrokayan SA. Development of polymeric nanoparticles of Garcinia mangostana xanthones in eudragit RL100/ RS100 for anti-colon cancer drug delivery. Journal of Nanomaterials. 2015;2015:1-12.

23. Rismana E, Kusumaningrum S, Bunga O, Nizar, Marhamah. Pengujian aktivitas antiacne nanopartikel kitosan-ekstrak kulit buah manggis (Garcinia mangostana). Media Litbangkes. 2014;24(1):19-27.

24. Chen LL, Tooley I, Wang SQ. Nanotechnology in photoprotection. In: Nasir et al, editor. Nanotechnology in Dermatology. New York: Springer International Publishing; 2013.

25. Kim SK, Ravichandran YD, Khan SB, Kim YT. Prospective of the cosmeceuticals derived from marine organisms. Biotechnology and Bioprocess Engineering. 2008;13:511-23.

26. Tsai TC, Hantash BM. Cosmeceutical agents: A comprehensive review of the literature. Clinical Medicine Dermatology. 2008;1:120.

27. Ramamoorthy PK, Bono A. Antioxidant activity, total phenolic, and flavonoid content of Morinda citrifolia fruit extract from various extraction processes. Journal of Engineering Science and Technology. 2007;7080.

28. Butnairu M, Grozea L. Antioxidant (antiradical) compounds. Journal of Bioequivalency and Bioavailability. 2012;4(6):xvii-xix.

29. Suttirak W, Manurakchinakorn S, Suttirak W and Manurakchinakorn S. In vitro antioxidant properties of mangosteen peel ex- 
tract. Journal of Food Sciences and Technology. 2014;51(12):3546-58.

30. Zarena AS, Sankar KU. A study of antioxidant properties from Garcinia mangostana L pericarp extract. Acta Scientarium Polonorum. 2009;8(1):23-34.

31. Tjahjani S, Widowatia W, Khiong K, Suhendraa A, Tjokropranoto R. Antioxidant properties of Garcinia mangostana $\mathrm{L}$ (mangosteen) rind. Procedia Chemistry. 2014;13:198 - 203.

32. Kondo M, Zhang L, Ji H, Kou Y, Ou B. Bioavailability and antioxidant effects of xanthone-rich mangosteen (Garcinia mangostana) product in humans. Journal of Agricultural and Food Chemistry. 2009;57:8788-92.

33. Ganceviciene R, Liakou AI, Theodoridis A, Makrantonaki E and Zouboulis CC. Skin anti-aging strategies. Dermato-Endocrinology. 2012;4(3):308-19.

34. Assi RA, Darwis Y, Abdulbaqi IM, Khan AA, Vuanghao L, Laghari $\mathrm{MH}$, et al. Morinda citrifolia (Noni): A comprehensive review on its industrial uses, pharmacological activities, and clinical trials. Arabian Journal of Chemistry. 2015; 10:691-707.

35. Alam M, Havey J. Photoaging. In: Draelos ZD, editor. Product Cosmetic Dermatology and Procedures. Blackwell Publishing; 2010.

36. Donglikar MM, Deore SL. Sunscreens: A review. Pharmacognosy Journals. 2016;8(3):171-9.

37. Zillich OV, Weisz US, Eisner P, Kerscher M. Polyphenols as active ingredients for cosmetic products. International Journal of Cosmetic Science. 2015;37:455-64.

38. Liandhajani, Iwo MI, Sukrasno, Soemardji AA, Hanafi M. Sunscreen activity of $\alpha$-mangostin from the pericarps of Garcinia mangostana Linn. Journal of Applied Pharmaceutical Science. 2013;3(6):70-3.

39. Fitri EW, Anwar AI, Djawad K, Seweng A, Changara H, Gemini A. The Effectiveness of topical mangosteen pericarp extract on the collagen of mice skin exposed to ultraviolet B. American Journal of Clinical and Experimental Medicine. 2016;4(3):88-93. 